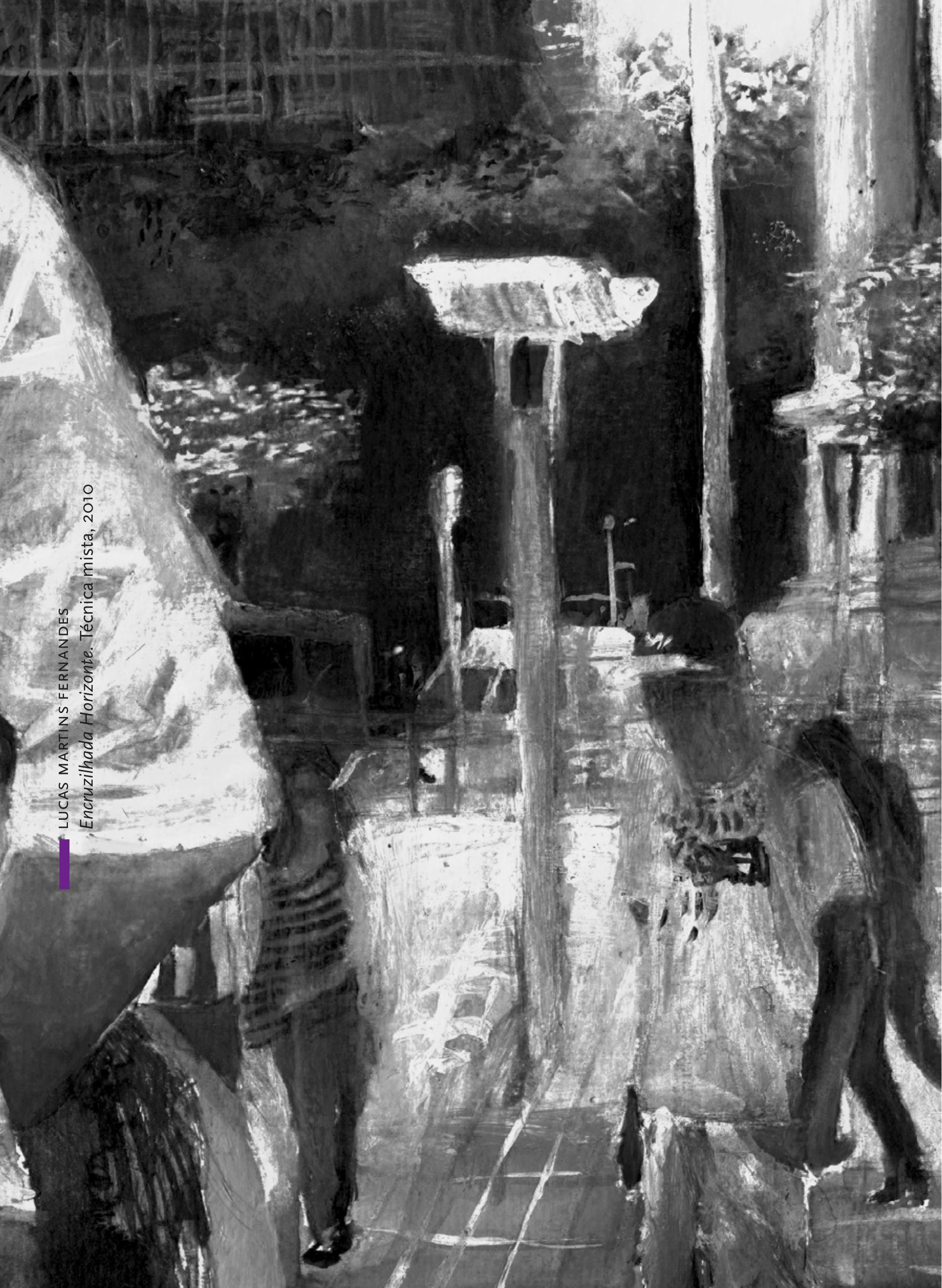




\section{PARA ALÉM DE POSTMETROPOLIS}

EDWARD W. SOJA:*

RESUMO Três recentes desdobramentos criaram novos desafios e oportunidades para a geografia urbana e os geógrafos, que incluem a redescoberta do poder gerativo das cidades, a difusão transdisciplinar das perspectivas espaciais críticas e o crescente interesse em regiões e no regionalismo. Tendo esses novos desdobramentos como pano de fundo, reflito sobre algumas ideias e temas introduzidos em Postmetropolis: Critical Studies of Cities and Regions, publicado em 2000. Como o livro, esta prospecção além de Postmetropolis divide-se em três partes: Remapeando a geohistória do espaço-cidade, Seis discursos sobre a pós-metrópole, e Espaço vivido: lembrando 1992 em Los Angeles.

PALAVRAS-CHAVE Estímulo da aglomeração urbana. A virada espacial. Urbanização regional.

\section{BEYOND POSTMETROPOLIS}

ABSTRACT Three recent developments have created new challenges and opportunities for urban geography and geographers. They include the re-discovery of the generative power of cities, the cross-disciplinary diffusion of critical spatial perspectives, and the rising interest in regions and regionalism. With these new developments as background, I reflect upon some of the ideas and themes introduced in Postmetropolis: Critical Studies of Cities and Regions, published in 200o. Like the book, this effort to move beyond Postmetropolis is divided in three parts: Remapping the Geohistory of Cityspace, Six Discourses on the Postmetropolis, and Lived Space: Remembering 1992 in Los Angeles.

KEYWORDS Stimulus of urban agglomeration. The spatial turn. Regional urbanization.

* Versão deste artigo foi publicada em Urban Geography, v. 32, n. 4, maio/jun. 2011.

**:Professor do Departamento de Planejamento Urbano da Luskin School of Public Affairs/University of California, Los Angeles - UCLA (Estados Unidos da América).E-mail: <esoja@ucla.edu>.

Revisão técnica da tradução de Roberto Luís de Melo Monte-Mór - Professor Associado do Centro de Desenvolvimento e Planejamento Regional da Faculdade de Ciências Econômicas e do Núcleo de Pós-Graduação em Arquitetura e Urbanismo da Escola de Arquitetura, ambas da Universidade Federal de Minas Gerais - UFMG (Brasil). 
1. Obviamente, a grande exceção foi a Escola de Ecologia Urbana de Chicago, com sua ênfase no comportamento humano modelado pelo ambiente urbano. Aqui, no entanto, a força causal foi externa ao comportamento social e generalizada como sendo ambiental ou ecológica. O conceito mais recente de causalidade espacial urbana provém não de forças "naturais", mas de geografias urbanas socialmente construídas (e, portanto, mutáveis).
E sta pode ser a melhor época para ser um geógrafo urbano. Não me refiro necessariamente à identidade disciplinar tradicional encontrada nos grupos especializados como a AAG (Associação de Geógrafos Americanos), mas a qualquer pessoa que se proponha a estudar como o espaço urbano é socialmente produzido e como essa espacialidade urbana ressoa afetando vidas individuais e coletivas. Uma perspectiva espacial crítica nunca esteve tão disseminada, tão direcionada para as cidades e a vida urbana e tão profícua em ideias inovadoras no que se refere à economia, política, cultura e mudança social de modo mais generalizado. Nos dias de hoje, nenhum estudioso, seja qual for seu interesse, pode se dar ao luxo de não ser, de alguma forma, um geógrafo urbano.

Esta abrangência intelectual sem precedentes de perspectivas geográficas urbanas coincide com um surto de crescimento urbano que levou as Nações Unidas a declararem que a maior parte da população mundial vive hoje em cidades. Entretanto, mais importante do que meros números que concentram a atenção popular e a dos estudiosos em cidades e geografias urbanas, eis que surgem, com força total no século XXI, três desdobramentos inter-relacionados e extraordinários, provenientes de fontes mais antigas.

I. A (re)descoberta da causalidade espacial urbana, a poderosa força gerativa das cidades e o processo de urbanização. A filosofia e a teoria social ocidental, seja qual for sua tendência política, raramente conferiram significativo poder explicativo à condição urbana. As coisas acontecem nas cidades, mas muito raramente por causa de influências especificamente urbanas. Neste sentido, a geografia urbana era pouco mais do que um reflexo de processos sociais, com pouco efeito autônomo em si. ${ }^{I}$ Por volta da década passada, principalmente como resultado do rigor de uma subdisciplina híbrida da economia geográfica, uma formidável percepção de que as cidades, em particular as geografias urbanas, produzem uma força gerativa que seria a causa primordial do desenvolvimento econômico, da inovação tecnológica e da criatividade cultural. Em 
uma reviravolta revolucionária, o que grosso modo denomino causalidade espacial urbana deixou de ser praticamente ignorado como um fator explicativo no desenvolvimento individual e societário para tornar-se, para alguns, a força motriz mais importante dando forma à história humana. Livros didáticos recentes começaram a chamar a esta força gerativa de Externalidades Jacobianas, em homenagem ao trabalho da urbanista Jane Jacobs, cuja obra The Economy of Cities (I969) é amplamente reconhecida por economistas vencedores do Prêmio Nobel e outros por promover a noção original do estímulo da aglomeração urbana, ${ }^{2}$ ou aquilo que chamo de synekism em Postmetropolis. ${ }^{3}$

Outros termos usados para descrever este poder gerativo das cidades são economias de urbanização (com referência retroativa às antigas teorias de economias de aglomeração e de formação de distritos industriais de Alfred Marshall) e buzz, termo cunhado por Storper e Venables (2004) para designar o papel estimulador do contato face a face. ${ }^{4}$ Suponho que brevemente essas noções de causalidade espacial urbana evoluirão para um conceito novo e mais abrangente de capital espacial, acompanhando o recente desdobramento da noção relacionada de capital social.

2. A virada espacial transdisciplinar nas ciências sociais e humanas. A notável e inédita difusão do pensamento espacial - em especial o que se refere à causalidade espacial urbana - tem ajudado a atrair um público maior para as novas ideias sobre a geografia urbana, permeando quase todas as ciências sociais e humanas, bem como adentrando o pensamento marxista e socialista radical. Tal virada espacial foi inicialmente desencadeada em Paris, principalmente a partir das perspectivas espaciais transformativas de Henri Lefebvre e Michel Foucault, mas posteriormente
2. O economista Robert Lucas Jr. (1988), vencedor do Prêmio Nobel, prestigia Jacobs e emprega suas percepções para reconstruir o campo da economia desenvolvimentista, ao passo que Richard Florida, o empreendedor mais engajado em promover a causalidade espacial urbana por meio de seu trabalho junto à "classe criativa" (FLORIDA, 2002), também reconhece a inspiração de Jacobs e advoga que as suas ideias revolucionárias sobre o poder gerativo das cidades seriam merecedoras de um Prêmio Nobel. As Externalidades Jacobianas foram primeiramente identificadas e discutidas como tal em Glaeser et al. (1992), e o termo foi empregado mais recentemente em alguns poucos livros didáticos de economia geográfica, tais como Brakman et al. (2009), embora seja difícil encontrar muitas referências a elas em livros didáticos da economia dominante ou de geografia econômica.

3. Synekism (N.T.: sem correspondência em português) deriva da palavra grega synoikismos, significando coabitar com eficiência (oikos = lar, a raiz da economia, ecologia e equística, o estudo dos assentamentos humanos). Synoikismos foi empregado por Aristóteles, Tucídides e outros com referência à formação da cidade-Estado ou pólis, uma unificação de diversas comunidades. Em grego moderno, pode também significar "casamento". Para uma discussão mais elaborada de synekism e o estímulo da aglomeração urbana, vide Postmetropolis e Soja (2000a e 2003a).

4. O subtítulo original do artigo sobre buzz era a "força econômica das cidades", uma frase que foi retirada, segundo relato, por solicitação de um editor da revista que julgava que os leitores não entenderiam uma noção tão presunçosa e pouco familiar tal como "cidades gerando forças desenvolvimentistas". 
5. Muito desta história foi discutido em Postmetropolis, mas a profundidade e amplitude da virada espacial ainda não era discernível. Desde 2000, o crescente interesse transdisciplinar pelo espaço reformulou meus compromissos na escrita e na docência. Fui convidado mais frequentemente a ministrar aulas e palestras fora da geografia, da arquitetura e do planejamento do que propriamente nessas disciplinas tradicionalmente espaciais, e cada vez mais públicos surpreendentes apareciam, ansiosos

por aprender mais acerca

do espaço e do pensamento espacial. Essas áreas cada vez mais diversificadas incluem antropologia urbana, história e prática da arte, crítica literária e literatura comparada, estudos de educação e alfabetização, arqueologia teórica, estudos jurídicos críticos, teoria do cinema, estudos pós-coloniais, estudos da escatologia e da Bíblia, teologia política, poesia, contabilidade, estudos de organização, e estudos da mídia e comunicação. Para mais detaIhes sobre isso, vide Soja (2008, 2010b, para teologia; 2002b, para arqueologia).

6. ESDP é discutida em Faludi e Waterhout (2002) e novas reflexões são feitas em Faludi

(2009). Veja também Soja (2009d). Há 15 anos, teria sido quase inconcebível alguém até mesmo pronunciar a frase

"perspectiva de desenvolvimento espacial", muito menos vê-la sendo adotada como uma política pública formal da União Europeia. perdeu força, após os eventos de I968, e foi eventualmente descartada por ser supostamente incompreensível, ou pior, como uma heresia fetichista, mormente por pensadores espaciais marxistas, cuja nova economia política urbana deixava pouco espaço para a causalidade espacial. Essas novas vertentes no pensamento espacial foram retomadas no mundo anglofônico no início dos anos I990, após a publicação em inglês da obra de Lefebvre, The Production of Space, em I991, ano de sua morte, sendo que mais tarde elas rapidamente tomariam rumo entre as diversas disciplinas como primeiro caminho para a adoção e aplicação de uma perspectiva espacial contemporânea e crítica. Embora ainda não esteja claro o porquê desse ressurgimento no período em que ele aconteceu, pode-se afirmar hoje que nunca antes, pelo menos nos últimos 200 anos, uma sensibilidade espacial crítica teve tanta projeção e influência nos debates contemporâneos, tanto acadêmicos quanto populares. ${ }^{5}$

3. O ressurgimento do interesse por regiões e regionalismo. A crescente relevância do pensamento espacial não somente esteve atrelada a uma renovada atenção às questões urbanas, mas ainda estimulava e era estimulada pelo ressurgimento do interesse por regiões e regionalismo. Em uma das mais ambiciosas expressões de seu “novo regionalismo”, Michael Storper em The Regional World (I997) concebe regiões como comparáveis a mercados, estados e ao parentesco, como estruturas organizacionais fundamentais da sociedade humana, enquanto a rede de aglomerações gerativas que formam a cidade-região (city region), já em si um novo conceito, seria a primeira força motriz por trás da globalização e da nova economia. Após anos de submissão a um empreendedorismo nocivamente competitivo, movido mais por um desenfreado marketing urbano do que preocupado em reduzir a pobreza e a desigualdade, o planejamento regional do bem-estar está sendo reanimado no âmago de um processo de planejamento espacial redefinido em múltiplas escalas, talvez melhor exemplificado pela Perspectiva de Desenvolvimento Espacial da União Europeia (ESDP), hoje uma política oficial em todos os países da UE. ${ }^{6}$ Estas novas abordagens regionais não são uma alternativa para um foco nas cidades mas constroem, em nossa compreensão do processo de urbanização e da metrópole moderna mutante, uma dimensão regional poderosa e mais explícita, a 
ponto de agora podermos falar de um processo de urbanização regional que vem reformulando radicalmente a estrutura metropolitana existente.

Apesar das extraordinárias oportunidades que oferecem para liderança intelectual nas ciências sociais espacializadas e nas humanas, os geógrafos, em sua maioria, não aceitaram de imediato esses extraordinários desdobramentos. Por exemplo, a nova ênfase na causalidade espacial urbana gera entre os geógrafos, não raro, uma nevrálgica recordação de feridas intelectuais regionalismo associadas a antigas incursões por formas de um determinismo geográficoambiental, e uma precaução, senão um tabu, quanto a formas aparentemente exageradas de explanação geográfica. Explanação em geografia é uma coisa aceitável; explanação pela geografia já seria outra coisa. Quanto à virada espacial, em vez de encorajar e estender seu desdobramento, muitos geógrafos reagem perguntando cinicamente: que virada? Mas não fomos sempre espaciais? “Em todo caso”, dizem eles, “os novatos não fazem geografia tão bem quanto nós", acomodados em suas ideias geográficas antiquadas e desatualizadas, ou então em metáforas superficiais, ainda que eruditas, como "mapeamento" disto ou daquilo, não percebendo as "reais" geografias subjacentes. ${ }^{8}$ Para esses geógrafos, o novo regionalismo também é visto como algo que não é tão novo, e suas ligações com o planejamento regional do bem-estar, alegam alguns mais radicais, nada mais são do que manipulações corporativas e dos poderes estatais neoliberais. Mesmo o renascimento da ciência regional, que se seguiu ao interesse renovado em regiões, é considerado por alguns geógrafos como apenas mais uma tentativa grandiosa de absorver a geografia em seu estrato nominal e pseudocientífico. ${ }^{9}$
7. Voltarei a este conceito de urbanização regional posteriormente neste ensaio.

8. Um debate bastante fútil, que desviou a atenção do progresso do nosso entendimento de economias de urbanização e das Externalidades Jacobianas, envolveu geógrafos que criticavam os economistas geográficos, especialmente 0 ganhador do Prêmio Nobel Paul Krugman, por usarem ideias geográficas desatualizadas e por se atrelarem a uma forma de imperialismo acadêmico. Para uma introdução a estes debates e para a resposta mais recente de Krugman, vide Martin (1999), Mäki e Marchionni (2010) e Krugman (2010). Exemplificando o olhar crítico dos geógrafos econômicos sobre o conceito de clusters, e praticamente ignorando os debates pioneiros intimamente relacionados aos estímulos da aglomeração urbana pelos economistas geográficos, vide Asheim, Cooke e Martin (2006)

9. Esta desconfiança dos geógrafos sobre a nova ciência regional se refere às preocupações sobre o imperialismo acadêmico discutido em Mäki e Marchionni (2010), mencionados na nota anterior. 
Um dos meus objetivos neste trabalho, conforme reexploro algumas das ideias e temas que apresentei há mais de dez anos em Postmetropolis, é encorajar mais geógrafos a deixarem de lado seus velhos tabus e reservas e se engajarem entusiasticamente nesses novos e excitantes desdobramentos, não apenas como seguidores, mas como lideranças intelectuais.

\section{Uma breve retrospectiva de Postmetropolis 2000}

obra Postmetropolis foi, grosso modo, dividida em três partes, intencionalmen-
te refletindo a tríade de Lefebvre de práticas espaciais percebidas (coisas no espaço), representações do espaço concebidas (pensamentos sobre o espaço) e o nunca inteiramente apreensível e muitas vezes encoberto mundo dos espaços vividos, o equivalente espacial dos tempos vividos, como aqueles das biografias ou histórias sociais. Enfatizando o aprendizado a partir das geografias concretas, a Parte I envolveu uma retrospectiva dos debates sobre a origem das cidades, baseada nos argumentos de Jacobs (I969) e em meu próprio conceito de synekism, discutindo os estímulos provenientes da aglomeração urbana. Esse caminho levou a uma geohistória da urbanização radicalmente revista, marcada por três revoluções geradas a partir do urbano, sendo a primeira associada ao desenvolvimento da agricultura; a segunda, ao surgimento dos estados centralizados; e a terceira, à emergência do capitalismo industrial (urbano). A ideia básica era ver quais novas descobertas empíricas poderiam surgir ao privilegiar uma perspecespacial, em vez de encorajar e estender seu desdobramento, muitos geógrafos tiva espacial crítica, ou parafraseando Jacobs, ao colocar em primeiro lugar a causalidade espacial urbana. A inspiração de toda a Parte I foi a assertiva de Jacobs de que, sem as cidades, seríamos sempre espaciais? 
todos pobres, teríamos permanecido na condição de caçadores e coletores nômades como fomos durante quase toda a história do homo sapiens.

A Parte II deu um salto para o presente para examinar os processos de reestruturação urbana que vêm reformulando as metrópoles modernas nos últimos quarenta anos. Elaborei, a partir de uma discussão anterior daquilo que denominei “Seis discursos sobre a pós-metrópole”, seis diferentes maneiras de se olhar para as profundas transformações urbanas que aconteceram desde os anos i960. A ênfase aqui está nos pensamentos sobre o espaço (representações e interpretações) em vez das coisas materiais no espaço (práticas espaciais). O termo pós-metrópole foi empregado como um conceito composto, propositalmente vago, que se refere aos diversos aspectos da mudança urbana que foram identificados e às literaturas específicas e espacialmente ricas (discursos) que emergiram do esforço de dar um sentido prático e teórico a essas mudanças.

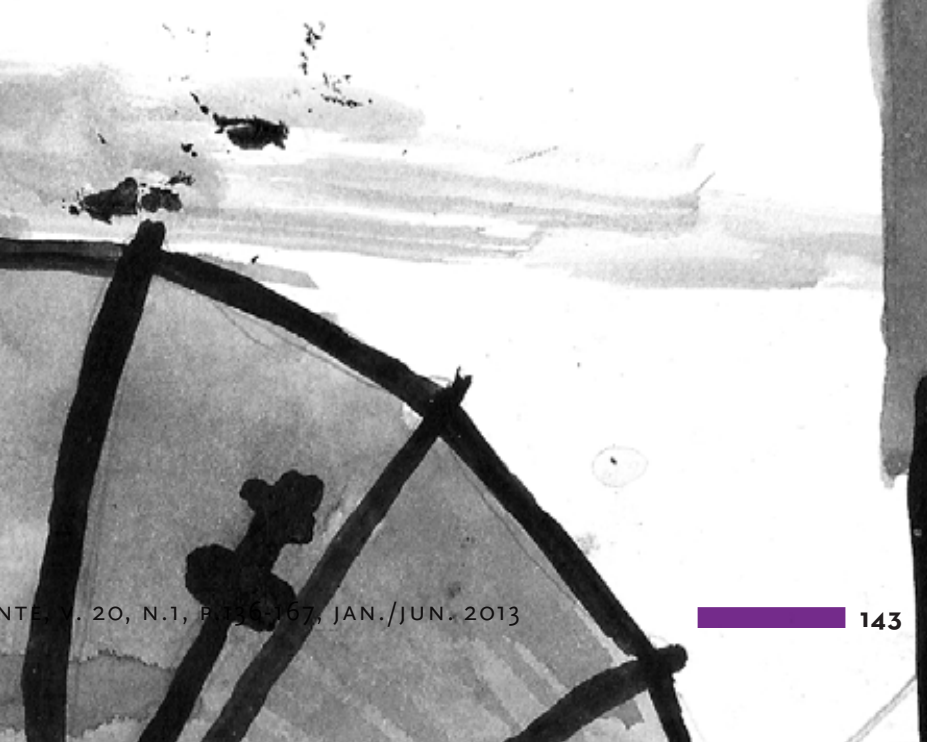


Os dois primeiros desses discursos representacionais foram explanatórios e causais, amalgamando ideias sobre a formação de uma nova e flexível economia pós-fordista altamente informativa; a globalização do capital, do trabalho, e da cultura, e a revolução complementar nas tecnologias da informação e das comunicações. Os dois discursos seguintes contemplaram os efeitos sociais e espaciais desses novos processos de urbanização, enfatizando a crescente diversidade cultural, as desigualdades econômicas e a polarização social crescentes, além das formas e funções urbanas mutantes. Os dois últimos, par final dos discursos, abordam as adaptações duras e fáceis à nova e cada vez mais volátil condição urbana, um deles envolvendo o urbanismo obsessivo com a segurança e o encastelamento da vida urbana, e o outro focalizando o uso de hiper-realidades simuladas para distrair a atenção dos problemas urbanos contemporâneos.

Em 2000, eu não sabia ao certo como descrever o que estava surgindo desses discursos sobre a “transição pós-metropolitana”. Por isso, identifiquei seis representações discursivas entrelaçadas da cidade contemporânea, e argumentei que todas as seis precisariam ser compreendidas conjuntamente, sem que esta ou aquela fosse considerada “a mais" importante. Hoje, estou muito mais confiante ao descrever essa transição mais especificamente como uma mudança profunda de um modo metropolitano de urbanização para algo que seria mais bem definido como urbanização regional. Como muito do que discuto neste ensaio, a identificação desta mudança profunda na natureza do processo de urbanização se origina e se sustenta nos três desdobramentos do século XXI mencionados anteriormente.

A Parte III de Postmetropolis colocou-me um desafio praticamente impossível: como ilustrar o significado completo de "espaço vivido", ou aquilo a que denominei “terceiro-espaço" (thirdspace) (SOJA, I996), voltando-me para Foucault e Lefebvre. Exatamente como o “tempo vivido” biográfico de alguém nunca seria completamente conhecível, assim também o mesmo se aplicaria ao espaço vivido (igualmente biográfico). Para falarmos minimamente de espaço vivido, é preciso selecionar e fazer escolhas entre as infinitas variedades de características, eventos e possibilidades, na esperança de produzir novos incrementos de conhecimento. Selecionei os eventos da Primavera de 1992 em Los Angeles, hoje conhecidos como Justice Riots [motins por justiça], para abrir uma janela sobre o que foi discutido nos capítulos anteriores. 
A discussão se baseou em trechos sequenciais e cuidadosamente selecionados de muitas e diversas fontes, inclusive um poema em prosa de minha autoria.

O último capítulo tornou-se uma reflexão crítica sobre a pós-metrópole em crise ou, como a descrevi, a mudança de décadas de reestruturação gerada por crises, para uma nova era de crises geradas pela reestruturação, ou seja, revoltas, motins e agitação que são uma resposta direta às novas condições pós-metropolitanas, ou àquilo que alguns chamam de urbanismo pós-moderno. Voltando o olhar para o quadro lúgubre que eu estava pintando da pós-metrópole, e tentando evitar explicações simplistas que culpariam o capitalismo neoliberal por todos os problemas do mundo, procurei encontrar algum fio de esperança, algum sinal de que as opressões, injustiças e desigualdades que se multiplicaram desde os anos I960 poderiam melhorar, se não pudessem ser apagadas. Na época, não percebi que isso desencadearia mais dez anos de pesquisa e escrita, levando à publicação de Seeking Spatial Justice em 20 o.

Mas chega de olhar para trás. O que veremos agora são algumas atualizações e revisões.

\section{Parte I: Antes - e após - Çatalhöyük}

o refletir sobre as recentes descobertas arqueológicas, bem como novas ava-
liações sobre os efeitos gerativos da urbanização, pode-se argumentar com mais firmeza que aquilo que denominei synekism - os efeitos estimulantes da aglomeração urbana - tem sido o fator primordial no desenvolvimento de todas as sociedades humanas por cerca de I2.000 anos, agora cada vez mais reconhecido como o tempo em que os primeiros assentamentos urbanos - as primeiras geografias urbanas intencionalmente criadas - começaram a se formar. Desde a era dos bandos de caçadores e coletores, cada sociedade humana foi influenciada pela existência de assentamentos urbanos permanentes, tornando a ausência de uma significativa causalidade espacial urbana na teoria social, na filosofia e na ciência ocidentais ainda mais surpreendente. A investigação dos debates sobre as origens das cidades não é somente uma espécie de concurso para se achar qual cidade veio primeiro, mas oferece uma oportunidade de acrescentar uma dimensão espacial significativa a esses debates e aprimorar a compreensão, com fins históricos e contemporâneos, 
10. É tentador chamar a este salto de grande escala primeiro

big bang do desenvolvimento societário humano, um afastamento da acomodação de uma crua condição natural para o "cozimento" de uma natureza transformada, o espaço socialmente construído de assentamentos humanos permanentes.

11. A literatura mais contemporânea sobre caçadores e coletores pode ser retrospectivamente projetada até esse momento das origens urbanas. Hoje é amplamente aceito que caçadores-coletores muitas vezes encontravam sustento com certa facilidade, especialmente em áreas como as terras altas da Anatólia neolítica, onde plantas e animais selvagens eram especialmente abundantes. Quase certamente, a agricultura e a domesticação de animais eram conhecidos dos mais antigos caçadorescoletores que moravam em cidades, mas a agricultura plenamente desenvolvida se tornou necessária somente ao longo do tempo, quando a reprodução de assentamentos urbanos permanentes fez com que se buscassem novas fontes de alimentos e outras necessidades básicas mais urgentemente. Pensando espacialmente, também faz pouco sentido para fazendeiros

(ou, neste caso, caçadores e coletores) se aglomerarem em um local. A vantagem básica da aglomeração era concernente ao comércio, especialmente de produtos pesados como pedras. dos efeitos gerativos da aglomeração urbana sobre o desenvolvimento econômico, a inovação tecnológica e a criatividade cultural.

Rígidas crenças canônicas sobre as origens sumérias posteriores das cidades persistem e estão associadas aos contínuos pressupostos que consideram a urbanização mais como um efeito do que uma causa, estabelecendo um elo entre o surgimento das cidades e certas justificativas como mudança climática, a emergência da língua escrita (e, portanto, a história, e não a “pré-história” escrita), a expansão da agricultura irrigada, o necessário acúmulo de um excedente de alimentos e o surgimento da civilização (eurocentricamente definida). O que vem se revelando cada vez mais, no entanto, é que a urbanização e o desenvolvimento agrícola (não simplesmente a domesticação das plantas) evoluíram em conjunto numa relação mutuamente estimulante pelo menos 6.000 anos antes da construção de cidades sumérias; que os assentamentos urbanos mais antigos foram formados por caçadores e coletores relativamente igualitários, com enorme habilidade para construções em pedra e artes visuais; que houve um salto em escala dos assentamentos de curto prazo em locais propícios de no máximo 300 pessoas para redes de centros urbanos ligados ao comércio de até Io.০o० habitantes:io e que o modelo de evolução das aldeias, pelo qual as aldeias agrícolas cresciam em tamanho até que se tornassem cidades, é pura mitologia com pouca ou nenhuma comprovação. Em vez da agricultura levando à urbanização, o inverso - ou pelo menos sua evolução paralela está se tornando mais provável. ${ }^{\text {II }}$

Eram cidades esses antigos assentamentos urbanos? Se ficarmos confinados a uma rígida crença de que cidades e civilizações surgiram somente com a escrita, irrigação em larga escala e divisões de trabalho mais elaboradas, então observaremos que grandes locais antigos como Jericó e Çatalhöyük seriam anomalias, experimentos inexplicáveis, mas não exatamente bem-sucedidos na criação de cidades. Todavia, se definirmos as cidades como aglomerações mensuráveis e relativamente permanentes que podem gerar novas ideias em tecnologia, em atividade econômica e nas artes, então pelo menos os antigos assentamentos de maiores proporções merecem ser chamados de cidades. Mesmo deixando de lado o modo como cidade é definida, sempre uma questão controversa e confusa, resta hoje pouca dúvida de que a extraordinária inventividade e inovação - na produção agrícola e 
na criação de animais, no desenvolvimento de crenças religiosas e nas distintas culturas humanas, na metaPara falarmos minimamente de espaço vivido, é preciso selecionar e fazer escolhas lurgia, no adorno pessoal, na produção de cerâmica, de tapetes, nas artes plásticas e representativas - surgiu do estímulo da aglomeração urbana, e esses efeitos gerativos continuaram entre as infinitas variedades de características, eventos e operando, até o presente, como uma fonte primária de desenvolvimento e de mudança da sociedade. Esta explicação espacial não nega a importância dos fatores ambientais, tais como a mudança climática, mas ainda assim coloca em primeiro lugar a urbanização, insistindo que os efeitos dos fatores ambientais e eventos “naturais” sejam vistos no contexto social da produção do espaço urbano.

Uma nova geografia do antigo processo de urbanização vem surgindo a partir de evidência arqueológica recente. Os primeiros assentamentos começaram bem a leste de Çatalhöyük, o foco da discussão em Postmetropolis, em uma área central sul da Anatólia, onde parece que o assentamento urbano e o total desenvolvimento agrícola andavam lado a lado, dando início a uma evolução paralela de desenvolvimento econômico e de urbanização que prosseguiria por I2.000 anos. O ponto de partida agora ficou claro, tanto que já há alegações de que o Jardim do Éden foi finalmente descoberto, e que este mito das origens tão sustentado se relaciona simbolicamente à mudança revolucionária da caçada para a agricultura baseada na urbanidade. Hoje, Göbekli Tepe é considerada a construção humana permanente mais antiga de que se tem notícia, uma resplandecente coleção de pelo menos 35 colunas de calcário que encimam mais de doze círculos de pedra. ${ }^{\text {I2 }}$ É difícil imaginar, mas este local de uma cantaria em larga escala e extraordinariamente avançada foi construído por caçadores e coletores cada vez mais sedentários, e antecedeu as pirâmides egípcias e Stonehenge em mais de 8.000 anos, assim como as primeiras cidades-Estado da Suméria em pelo menos 6.000 anos.
12. Klaus Schmidt, o arqueólogo alemão que liderou as escavações e interpretações de Göbekli Tepe, não identifi-

ca qualquer assentamento permanente no local, mas nas cercanias há evidência de uma ocupação humana relativamente densa, e a 15 quilômetros encontra-se a antiga Urfa, hoje Şanlıurfa, estabelecida aparentemente há 11.000 anos, que ainda existe hoje como uma cidade de aproximadamente meio milhão de habitantes. Se significantes interrupções em sua existência não tivessem ocorrido, Urfa seria a cidade continuamente habitada mais antiga do mundo. Para uma visão geral de Göbekli Tepe e os debates especulativos que gerou, ver Curry (2008). 
Os notáveis e ainda controversos achados em Göbekli Tepe sugerem que locais de cerimônias de adoração, realizadas de forma monumental, precederam ou ocorreram simultaneamente a assentamentos humanos permanentes. O que este local também confirma é que a transformação social de ambientes naturais, associada à criação de aglomerações urbanas, foi iniciada por caçadores e coletores, e foi o que propiciou, e não seguiu, uma revolução agrícola. É interessante notar que, não longe de Göbekli Tepe, foram encontradas as "plantações fundantes" originais das espécies mais remotamente cultivadas de vários grãos e legumes, inclusive trigo selvagem (einkorn wheat), a espécie que precedeu o trigo moderno. Como já mencionei em Postmetropolis, esta área do centro-sul da Anatólia foi também o primeiro local em que ocorreu a domesticação de ovelhas, porcos, cabras e gado, além de plantações de uvas, olivas, cevada, faro, trigo comum, ervilhas, favas, lentilhas e linhaça (Postmetropolis, p. 22).

A despeito das várias evidências que fundamentam a evolução simultânea da urbanização e da agricultura, persiste uma grande resistência a diversas ideias fundamentais: I) que o desenvolvimento da agricultura em larga escala e a produção de um excedente social de alimentos precisavam do estímulo da aglomeração urbana, e não o contrário; 2) que os caçadores-coletores igualitários e comerciantes, e não fazendeiros, produziram as primeiras cidades, não por meio de um crescimento progressivo das ideias, mas por um salto em escala a partir de pequenos assentamentos semipermanentes; e 3) que assentamentos como Jericó e Çatalhöyük merecem ser chamados de cidades, e não meras aldeias (agrícolas) que cresceram demais.

Entretanto, descobertas recentes quanto aos efeitos gerativos das cidades aliados à virada espacial sem precedentes e a alguns aspectos do novo regionalismo estão finalmente enfraquecendo esta resistência canônica. De certa forma comparável ao que aconteceu nas ciências da terra quando teorias de placas tectônicas revolucionaram um pensamento anterior a respeito do deslocamento continental, a crescente pesquisa em forças econômicas, políticas e culturais provenientes de geografias urbanas provavelmente levará a mudanças radicais tanto na economia do desenvolvimento contemporâneo quanto na geografia humana crítica, bem como na arqueologia, paleoantropologia e geo-história das sociedades humanas. 
O ocorrido na Suméria há 6.000 anos (e cerca de 6.000 anos após Göbekli Tepe) não foi o início da primeira e única Revolução Urbana, como os livros didáticos ainda relatam, mas o desenvolvimento gerado pelo fator urbano do Estado centralizado e seu acompanhamento: a sociedade hierarquicamente organizada (SOJA, 2009b). A formação do Estado - a emergência da cidade-Estado ou pólis - foi associada a um outro importante salto na escala urbana, do máximo provável de I5.000 nas cidades neolíticas a novas e concorridas cidades muradas e expansivas que, em sua forma imperial, poderiam alcançar centenas de milhares de habitantes, como em Roma, no norte da China e na região central mexicana. ${ }^{13}$

O que também está ficando claro é que os Estados baseados em cidades (ou cidades baseadas em Estados) da Mesopotâmia foram resultado de uma longa evolução de antigas zonas de urbanização que se estenderam de oeste a leste da Anatólia até o Vale do Indo e, ao sul, atravessando o Levante até o Vale do Nilo. Embora não exista ainda uma literatura específica acerca disso, em breve será possível traçar na longa transição entre a primeira e a segunda revoluções urbanas, conforme minha definição, não somente o surgimento do Estado centralizado, mas ainda de diferenças de classe, do patriarcalismo, do uso da língua escrita, de fortificações defensivas incluindo muros de cidades, da reorganização de geografias urbanas e das mais antigas expressões de princípios democráticos. Os pontos de partida para este processo evolutivo incluem Jericó no Levante e Çayönü, e talvez Urfa, na região sudeste da Anatólia, cada uma com pelo menos II.000 anos, fundadas por caçadores e coletores relativamente igualitários; mas o maior e quase certamente o mais gerativo de todos os locais urbanos neolíticos conhecidos continua sendo a "sinecista” aglomeração de Çatalhöyük. I4

Ainda há muito por dizer sobre a atualização das discussões de origens urbanas do Estado, o desenvolvimento posterior
13. Em muitas partes do mundo, desde a antiga América Central maia à costa do Peru e do Equador e até a China e Sudeste Asiático, e mesmo na América do Norte e no leste da Europa, arqueólogos vêm encontrando provas muito mais antigas de urbanização do que tradicionalmente se pensou ser possível. Entretanto, a ideia de que a agricultura veio antes e que ela foi essencial para a formação das primeiras cidades permanece tão forte que deparar com a urbanização e a agricultura evoluindo lado a lado ainda surpreende muitos arqueólogos e estudiosos da pré-história.

14. Soja (2000a, 2002d). Preciso acrescentar um comentário final sobre Çatalhöyük, que visitei pela primeira vez em 2004. Eu havia tomado conhecimento de dois argumentos que contradiziam o que eu havia abordado em Postmetropolis, ambos envolvendo a extraordinária pintura parietal que eu alegava ser a primeira ilustração consciente do espaço-cidade ou geografia urbana, a segunda natureza criada que se origina de assentamentos urbanos permanentes. Alguns observadores diziam que o mural não poderia ter ilustrado o grande vulcão Hassan Dag, que estava muito longe para ser avistado. Dizem que talvez ele tenha sido pintado de memória por migrantes de outros assentamentos mais próximos da fonte vulcânica da valiosa obsidiana. Outros, às vezes inclusive o principal arqueólogo, lan Hodder, já diziam que o mural não era uma ilustração do assentamento, mas um desenho abstrato, talvez de um leopardo. Depois de algumas dúvidas, eu fiquei ainda mais convencido de que os meus primeiros argumentos estavam corretos quando subi até o topo do sítio de escavações de ÇataIhöyük e olhei para o sul. A colina se estendia até o seu máximo à direita e esquerda de onde eu me encontrava, enquanto, bem à minha frente, estariam os telhados de dezenas de casas espalhadas pela planície abaixo. A distância, mas aparentemente perto, havia outro vulcão com dois picos parecendo muito com o mural. Era o Kara Dag e não o Hassan Dag, sendo que eu descobriria mais tarde que ele também era uma fonte de obsidiana, ou vidro vulcânico. O que eu vi à minha frente era a cena que parecia a cópia exata do que havia sido pintado no mural. Eu nunca me senti tão convencido daquilo que eu havia escrito em Postmetropolis. 
da Revolução Industrial e o surgimento daquilo que deveria sempre ser descrito como capitalismo industrial urbano. O ponto básico, no entanto, é a reativação destas discussões provenientes dos três desdobramentos inovadores e gerativos mencionados anteriormente. Após dois séculos de relativa negligência, as interpretações espaciais do desenvolvimento humano e societário estão pelo menos recebendo igual atenção em interpretações sócio-históricas, o que está levando a novas descobertas radicalmente inovadoras sobre a importância das geografias urbanas.

15. Meus escritos sobre este tópico desde 2000 incluem Soja (2011a, 2011b, 2010a, 2009a, 2009d, 2005).

16. As Nações Unidas agora coletam dados sobre tamanhos de cidades baseados em cidades-região (city regions) e não em áreas metropolitanas ou definições a partir de termos como "Grande". O Bureau do Censo Americano vem também dando maior ênfase a medições em "áreas urbanizadas", uma vez que categorizações anteriores de áreas estatísticas metropolitanas ficam complicadas com o crescimento de redes regionais de cidades. Se todas as velhas regras fossem seguidas, muitas regiões urbanas consideradas áreas estatísticas definidas pelo Censo necessitariam ter sete ou oito cidades oficialmente indicadas. É também interessante e sintomático que informações sobre cidades menores norte-americanas sejam recenseadas tendo como base suas "aglomerações" (clusters).

\section{Parte II: Urbanização regional e o fim da Era da Metrópole ${ }^{15}$}

$\mathrm{D}$ a mesma forma que os debates sobre a geo-história do espaço-cidade (cityspace) estão promovendo revisões radicais de nossas noções das formas mais remotas de urbanização, assim também o nosso entendimento dos processos de reestruturação urbana dos últimos 30-40 anos vem propiciando novos e extraordinários desdobramentos em nosso pensamento a respeito de cidades contemporâneas e do processo de urbanização. À frente desses desdobramentos, na minha perspectiva, esteve a identificação de um processo de urbanização regional policêntrica, acompanhado por um relativo declínio do que pode ser descrito como um modelo distintamente metropolitano de crescimento e de mudança urbanos. A literatura urbana dominante ainda não reconheceu este modelo regional de urbanização de forma explícita, mas há sinais de que a transformação da urbanização metropolitana para a regional e o uso de termos associados tais como cidades-região e cidades regionais crescerão em importância para a análise geográfica urbana ao longo da próxima década. ${ }^{16}$

Um novo regionalismo foi reconhecido em Postmetropolis como uma característica fundamental do que denominei transição pós-metropolitana, mas a importância e a direção desta regionalização do urbano foram deixadas em aberto e sem especificação. Hoje estou convencido de que o que tem acontecido com as cidades 
ao longo dos últimos trinta anos pode ser mais bem descrito como uma mudança paradigmática na verdadeira natureza do processo de urbanização. Embora ainda em seus estágios primários, o processo de urbanização regional avançou o suficiente em algumas áreas metropolitanas para que as suas características definidoras fossem reconhecidas e Há alegações de que o Jardim analisadas, e para que os estudiosos urbanos começassem do Éden foi finalmente a entender que a era da me- descoberto, e que este mito trópole moderna pode estar das origens tão sustentado terminando, criando uma crescente necessidade de se relaciona simbolicamente novas estruturas para a com- à mudança revolucionária preensão e estudo das cidades e geografias urbanas. Antes de adentrarmos o processo de baseada na urbanidade urbanização regional com mais detalhamento, seria interessante começar com a emergência do modelo metropolitano a partir da cidade capitalista industrial dos primórdios, mais centralizada.

\section{Da urbanização centralizada para a metropolitana}

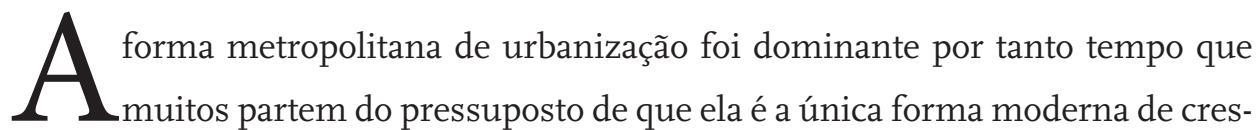
cimento e transformação das cidades. Este pensamento estanque colocou em nossa imaginação urbana o dualismo urbano-suburbano característico que somente começou a tomar forma no final do século XIX. Estou me referindo à divisão convencional da metrópole em dois mundos: um denso núcleo urbano, recheado de culturas heterogêneas, grossas camadas de interação social, concentrações de entretenimento e oportunidades de compras, além de crime, drogas, intrigas e pobreza; e, em contraste, um mundo suburbano, periférico e extensivo, onde um estilo de vida muito diferente é encontrado, muito mais homogêneo em matéria de classe e raça, preenchido de casas isoladas, jardins e famílias com filhos, todos 


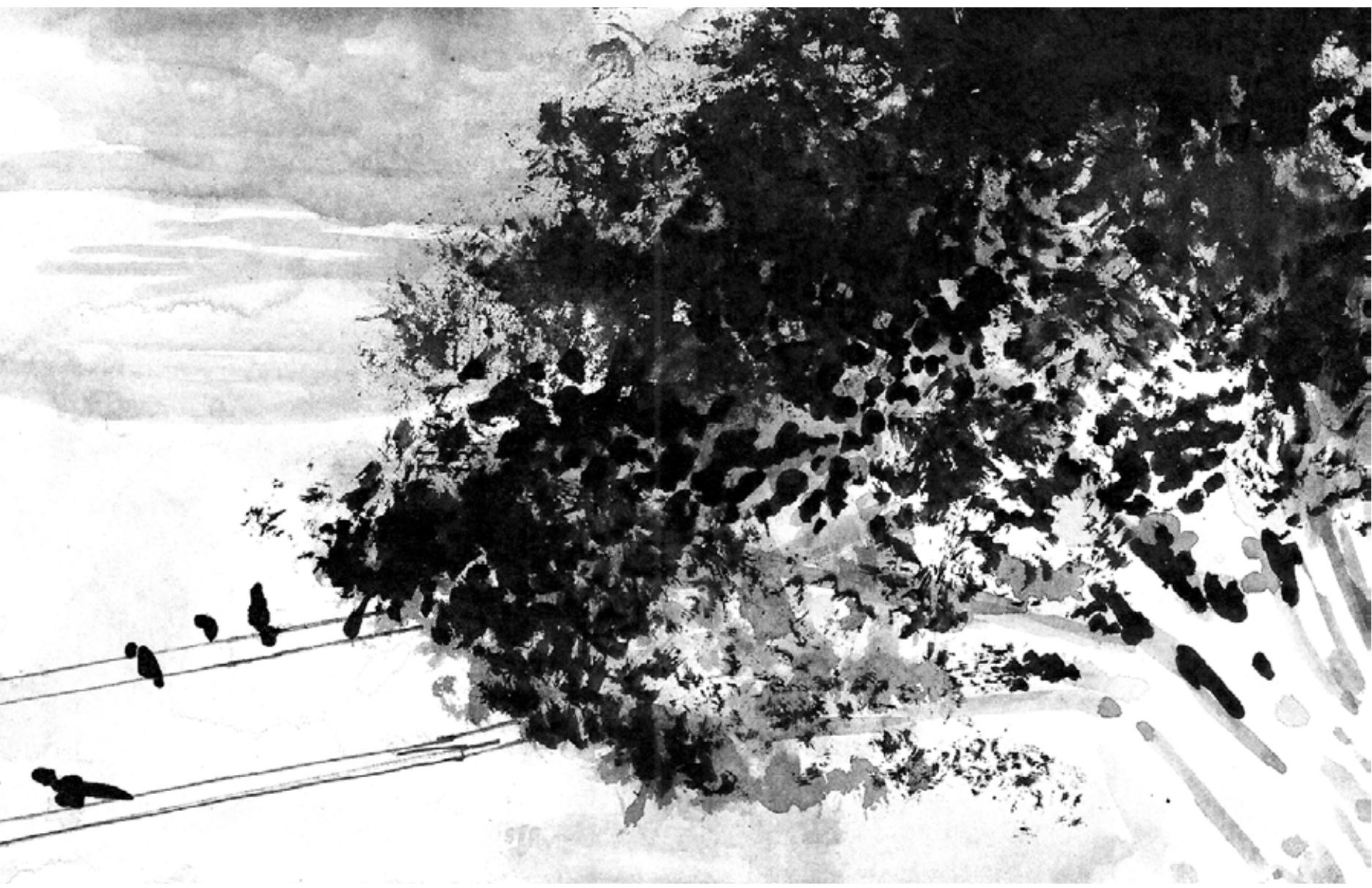

Pássaros no Fim da Tarde.

Nanquim sobre papel, 2010

dependendo de um grande número de automóveis e eletrodomésticos para quase todo aspecto da vida quotidiana.

A literatura sobre estudos urbanos reflete diretamente esta divisão dicotômica dos mundos urbanos. Este dualismo urbano-suburbano foi tão tenaz em sua influência sobre o nosso modo de pensar a cidade que, mesmo quando suas características essenciais começaram a desaparecer, como foi o caso nestes últimos trinta anos, as mudanças continuam despercebidas ou são então reabsorvidas dentro das mesmas velhas categorias dualistas. É interessante notar que algo muito semelhante ocorreu há um século, quando o modelo metropolitano emergiu de uma cidade muito mais centralizada, como era a cidade industrial capitalista do século XIX. 
Mesmo quando o desenvolvimento metropolitano avançava à sua volta, os estudiosos da Escola de Chicago desenvolveram modelos inovadores que se aplicavam não à Chicago de então, mas à forma urbana capitalista industrial do século XIX que ainda sobrevivia: compacta, densamente centralizada, com forças centrípetas e centrífugas emanando quase que totalmente da aglomeração residencial e industrial no centro pululante da cidade. Esta era literal e figurativamente "a cidade”, e foi esta cidade que dominou os estudos urbanos e, em especial, a teoria espacial urbana e a geografia urbana, largamente adentrando a era da metrópole moderna. ${ }^{\text {I7 }}$ Como o modelo metropolitano dos nossos dias, os modelos da Escola de Chicago eram altamente idealizados e fizeram parecer que este era o único modo pelo qual as cidades cresciam.

O que discuto primeiramente é que a urbanização metropolitana precisa ser reconhecida como uma fase distinta no desenvolvimento da cidade capitalista industrial; em segundo lugar, que se originou de uma fase anterior de um urbanismo industrial mais centralizado, que nunca se apagou por completo; e, finalmente, que este modo metropolitano de crescimento urbano está agora sendo suplantado e reconstituído, trazendo à tona uma nova fase de urbanização regional multiescalar.

\section{Urbanização regional em ascensão}

frente deste processo de urbanização regional vem se observando uma
crescente convergência de densidades entre as áreas urbana e suburbana. Os acentuados gradientes de densidade metropolitana que se estendem para além dos velhos centros urbanos estão se achatando enquanto densidades mais altas alcançam os subúrbios espraiados onde a baixa densidade existia em outras épocas. Tal incremento nos gradientes de densidade normalmente significava um relativo declínio da densidade (bem como da população) nas áreas centrais, enquanto os antigos subúrbios passavam por adensamentos significativos, mais frequentemente por meio de um padrão de urbanização por ocupação de espaços vazios do que mediante o espraiamento em direção às áreas limítrofes. À medida que se adensa, o que era um subúrbio relativamente homogêneo vem sendo cada vez mais diferenciado, tornando-se mais parecido com o velho núcleo urbano.
17. Certamente os geógrafos urbanos logo tentaram desenvolver variações dos clássicos modelos da Escola de Chicago, reconhecendo, por exemplo, os múltiplos núcleos que surgiam, especialmente com a suburbanização em massa. No entanto, o modelo clássico, com suas zonas concêntricas e ligações radiais, persistiu com poucas alterações na maioria das disciplinas dos estudos urbanos. 
Numa reviravolta quase oximorônica, o subúrbio está sendo crescentemente urbanizado enquanto a metrópole monocêntrica moderna se metamorfoseia em uma cidade regional policêntrica, abrangendo uma rede amplamente distribuída de aglomerações de variados tamanhos - uma nova geografia urbana.

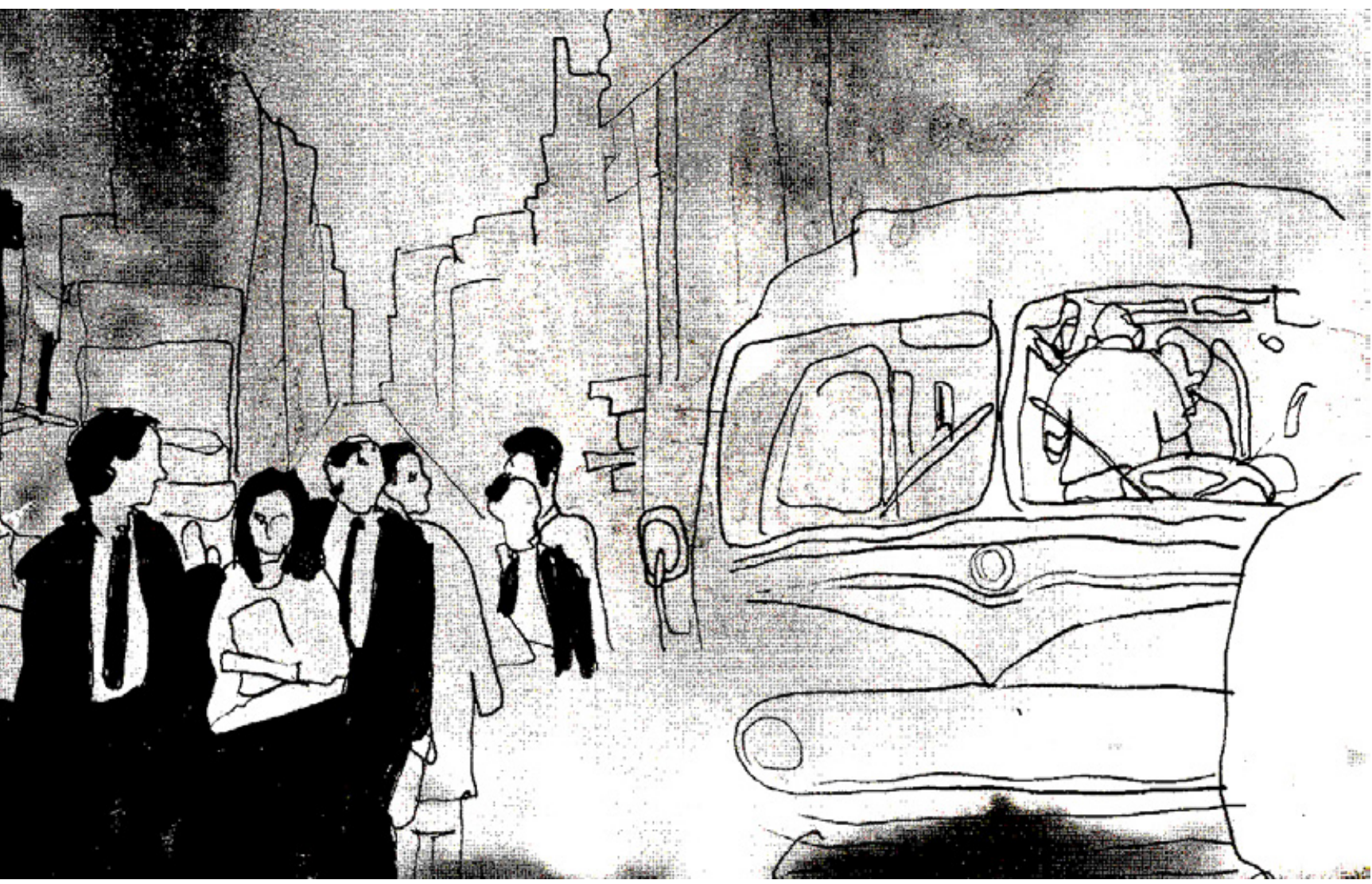

Sem título.

Técnica mista, 2012 
Um vocabulário distinto surgiu para descrever esta transição pós-metropolitana, conforme minha denominação em 2000. Os assentamentos avançados do pós-subúrbio que surgiram foram descritos como cidades limítrofes, cidades externas e metrourbes, ao passo que para além da velha fronteira da hinterland há uma confusa variedade de exurbes, áreas urbanas e assentamentos periurbanos. Conforme o gradiente de densidade aumenta, a urbanização periférica traz consigo uma heterogeneidade econômica e cultural crescente, um aumento de populações imigrantes e praticamente tudo o que for tradicionalmente associado às áreas centrais, apagando do mapa o que já fora uma fronteira de identificação relativamente fácil entre o mundo urbano e o suburbano. ${ }^{18}$ Em Postmetropolis, empreguei o termo “exópole” para descrever esta morfologia urbana mutante, com a jocosa percepção de seu duplo sentido tanto como "externo" (urbanização periférica) e "ex" como "não mais", a ex-cidade, uma nova forma urbana bem diferente da antiga. A exópole é agora integrada à ideia de urbanização regional.

Enquanto cidades periféricas se adensam praticamente por toda parte, as áreas centrais passam por muitas tendências diferentes, embora quase todas as maiores cidades-região do mundo tenham passado por algum tipo de "esvaziamento" ou densidade decrescente nas primeiras fases de reestruturação e desindustrialização. Dois casos extremos e contrastantes de emigração da cidade central são Detroit e Osaka, cada uma tendo perdido mais de meio milhão de residentes do núcleo urbano. Enquanto Detroit se tornou um símbolo de decadência urbana, o núcleo urbano de Osaka prospera, apesar de contar com muito poucos residentes. Em muitas outras cidades-região globalizadas, após um esvaziamento de populações domésticas, o centro se preencheu novamente com um grande número de imigrantes, sendo alguns dos exemplos mais destacados as cidades de Los Angeles, Nova York, Londres, Paris e Amsterdam. ${ }^{19}$

As experiências altamente variadas de áreas centrais vieram acompanhadas de uma crescente e, não raro, obsessiva preocupação com os centros em fase de declínio e um desejo, aparentemente endêmico, de renascimento e retomada de desenvolvimento. A urbanização regional policêntrica tornou os núcleos urbanos centrais muito mais instáveis e imprevisíveis, levando a um marketing urbano
18. Uma pesquisa comparativa rigorosa é hoje muito necessária, sobre as múltiplas formas que os subúrbios, antes homogêneos, estão agora tomando, desde redutos resistentes que protegem seus tradicionais valores suburbanos e seus ambientes construídos por meio de associações de moradores, até áreas onde as "comunidades" são completamente cercadas e vigiadas, como também cidades confinadas nas periferias que crescem rapidamente e nas quais as pessoas precisam viajar por mais de duas horas a cada ida e volta para trabalhar, e mesmo aquelas que são essencialmente cidades suburbanas oximorônicas, sendo algumas, como Orange County (adjacente a Los Angeles) e o Vale do Silício (sendo San Jose hoje a maior cidade da Bay Area amplamente definida) podem abrigar vários milhões de habitantes.

19. Com o intenso crescimento populacional de suas áreas centrais e periféricas, Los Angeles tornou-se um protótipo do processo de urbanização regional. Em 1990, Los Angeles ultrapassou Nova York no quesito área mais densamente urbanizada dos Estados Unidos, uma mudança notável considerando que Los Angeles foi provavelmente a menos densa metrópole americana em 1960. Desde então, a população da região urbana de L.A. cresceu em 8 milhões de pessoas, aproximadamente. Para mais informações sobre densidades urbanas, vide Demographia, 1990 US Urbanized Area Density Profile, disponível em: <http://www.demographia. com/db-porta.htm>. 
20. Tudo isso confunde a mensuração estatística agregada da segregação. Da mesma forma que pequenos aumentos na renda média ao longo do tempo podem mascarar a polarização da renda pronunciada, com grandes aumentos das populações pobres, e em menor grau das populações muito ricas, assim também os índices dos níveis de mudança na segregação são muitas vezes enganosos, dado que a segregação racial aumenta e diminui simultaneamente por várias razões diferentes. agressivo e a esforços para dar uma marca às cidades, deslocando o investimento, a política e o planejamento públicos de uma ênfase nas necessidades sociais básicas para um empreendedorismo altamente competitivo, utilizando recursos públicos de forma quase desesperada para atrair novos investimentos privados e a atenção de turistas. Em uma das tragédias mais irônicas da urbanização regional, enormes recursos públicos estão sendo desviados de esforços dedicados ao problema da pobreza, dos sem-teto e da desigualdade justamente numa época em que estes problemas passaram a ser mais significativos do que nunca. Um sombrio "planeta de favelas" (DAVIS, 2007) e um planejamento obcecado pelo desenvolvimento de “cidades criativas" (SCOTT, 2006) e os "efeitos Bilbao" estão entre os vários subprodutos da urbanização regional.

Possivelmente há concentricidades residuais e irradiações nas cidades-região reconstituídas pelo mundo e certamente persistem grandes faixas de subúrbios tradicionais. A metrópole moderna, no entanto, ficou cada vez mais "sem limites", e muitas de suas antigas estruturas espaciais e delimitações sociais e culturais tiveram sua força reduzida. Velhas geografias raciais e de classe estão ficando mais miscigenadas e heterogêneas, enquanto novos enclaves de culturas imigrantes brotam de uma geografia urbana reformulada que muitos percebem ser muito mais caótica e ameaçadora do que antes. ${ }^{20}$ Uma sensação endêmica de medo, cultivada em grande parte pela nova geografia urbana perturbadora e desconhecida, levou ao que Davis (I990) chamou de urbanismo obsessivo com a segurança, cheio de fortalezas, muros, cercas elétricas, comunidades enclausuradas e guardadas a poder de fogo, câmeras de vigilância, e uma sensação de perigo iminente.

Para piorar estas condições amedrontadoras, houve ainda a continuidade ou mesmo o aumento da polarização cultural, política, econômica e social. A concentração de riqueza naquele um por cento mais rico da população e o crescimento simultâneo de populações vivendo no limiar ou abaixo do nível de pobreza alcançaram níveis incomparáveis e certamente aumentaram desde o ano 2000 nos Estados Unidos e em vários outros países. Assim também, o antagonismo entre as populações imigrantes e domésticas, que aumentou em quase todas as 500 regiões urbanas de mais de um milhão de habitantes que concentram a população, a riqueza e a capacidade inovadora do mundo. Encabeçam a lista os Estados Unidos, que hoje 
apresentam o maior abismo entre ricos e pobres de sua história, sendo que estas e outras forças polarizadoras até pioraram desde o

Mesmo quando o desenvolvimento colapso econômico em 2008.

metropolitano avançava

Desde 2000 está ficando cada vez mais claro que as maiores cidades-região do mundo não à sua volta, os estudiosos da Escola de Chicago são apenas a força motriz primária desenvolveram modelos que impulsiona a econo- inovadores que se aplicavam mia global, mas são também altamente voláteis e geradoras de problemas não à Chicago de então, mas à forma urbana capitalista fundamentais de desigualdade e injustiça. Independentemente industrial do século XIX de como os novos processos de urbanização são definidos, pode-se argumentar que, após trinta anos ou mais de reestruturação gerada pela crise, entramos numa era de crises geradas pela reestruturação, com várias formas de agitações e rebeliões sociais, bem como uma recessão global cada vez mais profunda e derrocadas financeiras que são estimuladas diretamente pelo que venho descrevendo como processo de urbanização regional.

\section{As múltiplas escalas da urbanização regional}

extensão dos efeitos da urbanização regional se traduziu numa expansão
em escala bem além dos antigos limites do entorno da metrópole moderna. A urbanização metropolitana ocupou uma escala singular, entre o urbano ou municipal e a escala regional subnacional. A urbanização regional não somente pode ser definida em múltiplas escalas do local ao global; pode-se também argumentar de forma persuasiva que uma peculiar convergência escalar vem ocorrendo no crescimento de cidades-região ou cidades regionais. As escalas urbana, metropolitana e regional subnacional parecem estar se amalgamando em muitas partes do mundo, resultando no surgimento do que alguns agora chamam de regiões de 
21. Definir os limites externos da megarregião será provavelmente difícil e controverso por anos a fio. Um dos problemas é que o interior da megarregião é consideravelmente global.

22. Se lançarmos o termo "novo regionalismo" num mecanismo de busca, a maioria dos milhares de resultados refere-se a essas regiões supranacionais. É interessante notar que um processo semelhante de construção de coalizão está começando a acontecer em nível local quando organizações trabalhistas e comunitárias desenvolvem alianças flexíveis e estratégias especificamente regionais, revelando o que alguns chamam de regionalismo comunitário (SOJA, 2010). megacidades, megarregiões, regiões megalopolitanas, galáxias regionais ou mesmo regiões-Estado, imensas redes regionais de aglomerações. Em alguns casos, como em Barcelona-Catalunha, na recentemente definida região de Gauteng no entorno de Johannesburgo, e nas “Grandes” Paris, Londres, Nova York, Los Angeles, as megarregiões redefinidas variam entre 6 e 20 milhões de habitantes; mas no Rio Pearl e nos Deltas Yangtze da China, em Tóquio-Yokohama e Osaka-KobeKioto no Japão, e naquilo que Richard Florida chamou de Terras Baixas Europeias (da holandesa Randstad à recentemente formada Grande Região em torno do Luxemburgo), a população megarregional agora ultrapassa 50 milhões. ${ }^{21}$

Entre os muitos efeitos dessa forma estendida de urbanização regional e sua reestruturação escalar associada está uma crise agravada da governança regional e urbana (BRENNER, 2005). As velhas geografias administrativas e políticas de governos nacionais em todo o mundo têm figurado entre as geografias de mudança mais lenta nas últimas quatro décadas, especialmente quando comparadas às reorganizações econômicas e culturais do espaço. Esta crise na governança é também evidente nas escalas nacional e global em que houve uma explosão do dito regionalismo supranacional, enquanto os Estados-nação formam coalizões amplas para tratar do impacto da globalização, da nova economia e da revolução na tecnologia da informação. O modelo básico tem sido a União Europeia; outros exemplos incluem os vários e distintos blocos mercantis, tais como NAFTA, MERCOSUL e ASEAN. ${ }^{22}$

Portanto, o processo de urbanização regional se desdobra em várias escalas diferentes, do local ao global. De fato, o próprio processo de globalização tem sido portador da urbanização regional, estendendo a influência do capitalismo urbano industrial a praticamente todos os lugares, das cerca de 500 regiões megaurbanas com mais de um milhão de habitantes, que em breve conterão a maioria da população mundial, aos países recentemente industrializados, tais como os Tigres Asiáticos, bem como regiões recentemente industrializadas, como o Vale do Silício e o Condado de Orange, e até mesmo mais longe, adentrando a floresta amazônica, a tundra siberiana, o deserto do Saara e a calota polar da Antártica. Não houve somente uma globalização do urbano, trazendo populações de todos os cantos do planeta para as cidades-região globalizadas, mas também uma urbanização acelerada do mundo (SOJA; KANAI, 2008). 


\section{Parte III: Buscando justiça espacial}

$\mathrm{N}$ a terceira e última parte de Postmetropolis, ensaiei novas maneiras de pensar e escrever sobre espaço e geografia, e procurei novas áreas para espacializar. Eu estava movido pelo entendimento de que havia pintado um quadro negro e deprimente demais da metrópole moderna reestruturada, com desigualdades sem contrastantes de emigração precedentes, polarização da cidade central são Detroit social, obsessão pela segurança e vigilância, abane Osaka, cada uma tendo dono dos objetivos de perdido mais de meio milhão bem-estar social, liberde residentes do núcleo dades civis agonizantes, ecologia do medo e a incidência crescente de falta de moradia e se tornou um símbolo de pobreza. Se estivesse ensi- decađência urbana, o núcleo nando geografia ou sociologia, eu poderia acrescentar urbano de Osaka prospera mais e mais condenações ao capitalismo, racismo, patriarcalismo e ascendência neoliberal. Mas eu estava dando aulas em um departamento de planejamento urbano por várias décadas e precisava encontrar um meio de sensibilizar salas de aulas repletas de ativistas sérios comprometidos com a mudança do mundo para melhor. Algum espaço precisava se abrir para uma efetiva ação social.

Eu me perguntava: haveria alguma réstia de esperança na história da reestruturação urbana? Alguma coisa que pudesse oferecer uma abertura para o ativismo social progressista? Compondo tudo aquilo que eu vinha escrevendo a respeito por muitas décadas, cheguei à ideia de que pensar espacialmente e ver o mundo por lentes particularmente espaciais poderia por si só fornecer estratégias úteis para a mobilização de novas ações sociais, mais poderosas no tratamento das desigualdades, injustiças e opressões acumuladas do mundo contemporâneo. Respaldado pelos três novos desdobramentos no pensamento espacial e amparado pela 


\section{A urbanização regional policêntrica tornou os núcleos urbanos centrais}

obra do crítico pós-colonial Edward Said, lancei o foco sobre as endêmicas "lutas pela geografia" que foram muito mais instáveis e na e pela urbanização regional e sobre imprevisíveis, levando a um marketing urbano agressivo e a esforços para dar uma marca às cidades aquilo que descrevi como a busca pela justiça espacial, repensando justiça social e conceitos relativos de democracia, cidadania e igualitarismo a partir de uma perspectiva assertivamente espacial (isto é, causal). Mas onde eu poderia encontrar bons exemplos dessas lutas pela geografia e dessa busca estratégica por justiça espacial?

Talvez não surpreenda o fato de que eu tenha me voltado para Los Angeles como fonte de ilustração e inspiração. Isto apesar do fato de que, durante os últimos dez anos, a pesquisa baseada em Los Angeles tenha se tornado alvo de críticas devido às suas alegações aparentemente exageradas. Muitos estudiosos, dentro e fora de Los Angeles, haviam reagido duramente às assertivas do geógrafo planejador Dear (200I, 2008) de que havia uma distinta Escola de Los Angeles que tinha substituído a velha Escola de Chicago de Ecologia Urbana no núcleo representativo dos estudos urbanos contemporâneos. A maioria dos outros geógrafos e planejadores ligados ao expansivo grupo de pesquisa que surgira em Los Angeles, focalizando a análise espacial de forma assertiva, especialmente a partir de uma perspectiva regional, pouco interesse tinha em promover essa ideia de uma nova escola e alguns dos conceitos que Dear havia ligado a ela, embora houvesse algum entendimento geral de que Los Angeles havia gerado um grande corpo de pesquisa geográfica inovadora que favoravelmente se comparava a qualquer outro grupo de pesquisa baseado na questão urbana nos últimos quarenta anos. Posso ainda acrescentar que esta pesquisa local desempenhou um importante papel na redescoberta da causalidade espacial urbana, na virada espacial transdisciplinar e no novo regionalismo.

Por causa da confusão e da controvérsia em torno deste debate sobre a assim chamada Escola de Los Angeles e devido à larga reação negativa ao empreendedorismo 
de Los Angeles, hesitei em concentrar muita atenção em Los Angeles. Ainda assim, Los Angeles proporcionava exemplos especialmente claros para aquilo que eu buscava. Com o rico suporte da literatura acadêmica acumulada e com o novo pensamento sobre a causalidade espacial urbana, promovido pelo ressurgimento e disseminado interesse no espaço e nas abordagens regionais, comecei a explorar a ideia de que Los Angeles não era apenas um laboratório produtivo para o desenvolvimento da teoria espacial e para a pesquisa empírica informada pela teoria, mas era também o cenário para uma mais ampla extensão da virada espacial em direção àquilo que poderia ser chamado de práxis espacial, reais ações políticas e movimentos sociais erigidos, pelo menos em parte, sobre uma consciência espacial inovadora. Por volta do ano 2000 , houve frequentes alegações de que Los Angeles havia se tornado um centro inovador tanto para o movimento trabalhista americano quanto para organizações baseadas nas comunidades. Novas coalizões vinham emergindo, tais como a Bus Riders Union (Sindicato dos Usuários de Ônibus) e a Los Angeles Alliance for a New Economy (Aliança de Los Angeles pela Nova Economia), e estavam conseguindo sucessos significativos e inovadores.

Optei por escrever um livro de fácil leitura, discorrendo sobre o desenvolvimento das coalizões trabalho-comunidade em Los Angeles desde a United Farm Workers (União dos Trabalhadores Agrícolas) até o presente, com especial atenção às relações dessas coalizões com professores e estudantes universitários ao papel que o pensamento crítico sobre o espaço e, particularmente, as estratégias espaciais teve nesses desdobramentos. Para assegurar a compreensão, elaborei capítulos introduzindo a questão da virada espacial e alguns conceitos como a dialética socioespacial, mas procurei escrevê-los de forma a tornar a teoria acessível a leitores ativistas e estudantes, meu público primeiro.

A nova consciência espacial que argumentei estar orientando a busca pela justiça espacial pode ser apresentada por uma série de proposições geográficas básicas: I) geografias humanas são produzidas socialmente (refletindo a noção de Lefebvre da produção social do espaço social); 2) instiladas de poder social, essas geografias criadas podem ser tanto opressivas quanto capacitadoras (seguindo a conceituação de Foucault sobre as relações entre espaço, conhecimento e poder); 3) geografias opressivas ou injustas podem ser mudadas, tornadas menos opressivas e mais justas, por meio da ação socioespacial orquestrada; e 4) a nova consciência espacial e as 
lutas coletivas pela geografia podem fornecer um efeito unificador para a coalizão entre diversas organizações e movimentos sociais, aumentando a importância estratégica da busca por justiça espacial.

Devido ao contínuo sucesso de grupos como o Bus Riders Union e sua organização afiliada Labor/Community Strategy Center (Centro Estratégico Trabalhista/Comunitário), o Los Angeles Alliance for New Economy (LAANE, ou a Aliança de Los Angeles pela Nova Economia), o Strategic Actions for a Just Economy (SAJE, ou Ações Estratégicas por uma Economia Justa) e o recentemente formado Right to the City Alliance (Aliança do Direito à Cidade), Los Angeles veio a ser um dos centros mais importantes para o movimento trabalhista americano e um centro especialmente ativo de organizações baseadas em comunidades (em inglês, CBOs). Em parte, essa liderança nacional tem sido estimulada pelas geografias particularmente injustas e opressivas originadas pela globalização e pela reestruturação econômica. As desigualdades de renda e a polarização social são maiores em Los Angeles do que em quase qualquer outra cidade-região do mundo desenvolvido, e estão se igualando àquelas encontradas em Calcutá ou na Cidade do México.

O que pode ser descrito como a primeira maior explosão urbana contra a globalização, os tumultos e revoltas de I992, agora significativamente denominado Justice Riots, segundo o lema mobilizante "No Justice - No Peace” (Sem justiça não há paz), foi o marco de outro momento decisivo. Ficava cada vez mais claro que as investidas dos governos municipal, estadual e federal nunca seriam suficientes para lidar com os problemas que Los Angeles enfrentava; assim, organizações ativistas e a grande aglomeração dos trabalhadores menos favorecidos que havia se formado à volta do centro de Los Angeles entenderam que novos métodos e estratégias inovadoras eram necessários nas lutas por maior justiça econômica e social. Várias características distinguiram os movimentos que surgiram em Los Angeles das suas contrapartes em outras regiões metropolitanas. Uma delas foi o synekism criativo que surgiu dos quase 5 milhões de imigrantes trabalhadores de baixa renda concentrados no núcleo da região metropolitana, alcançando densidades urbanas comparáveis somente a Manhattan. Novas e urgentes necessidades foram geradas pela pobreza, falta de moradia e crise imobiliária induzidas por esta situação. De certa 


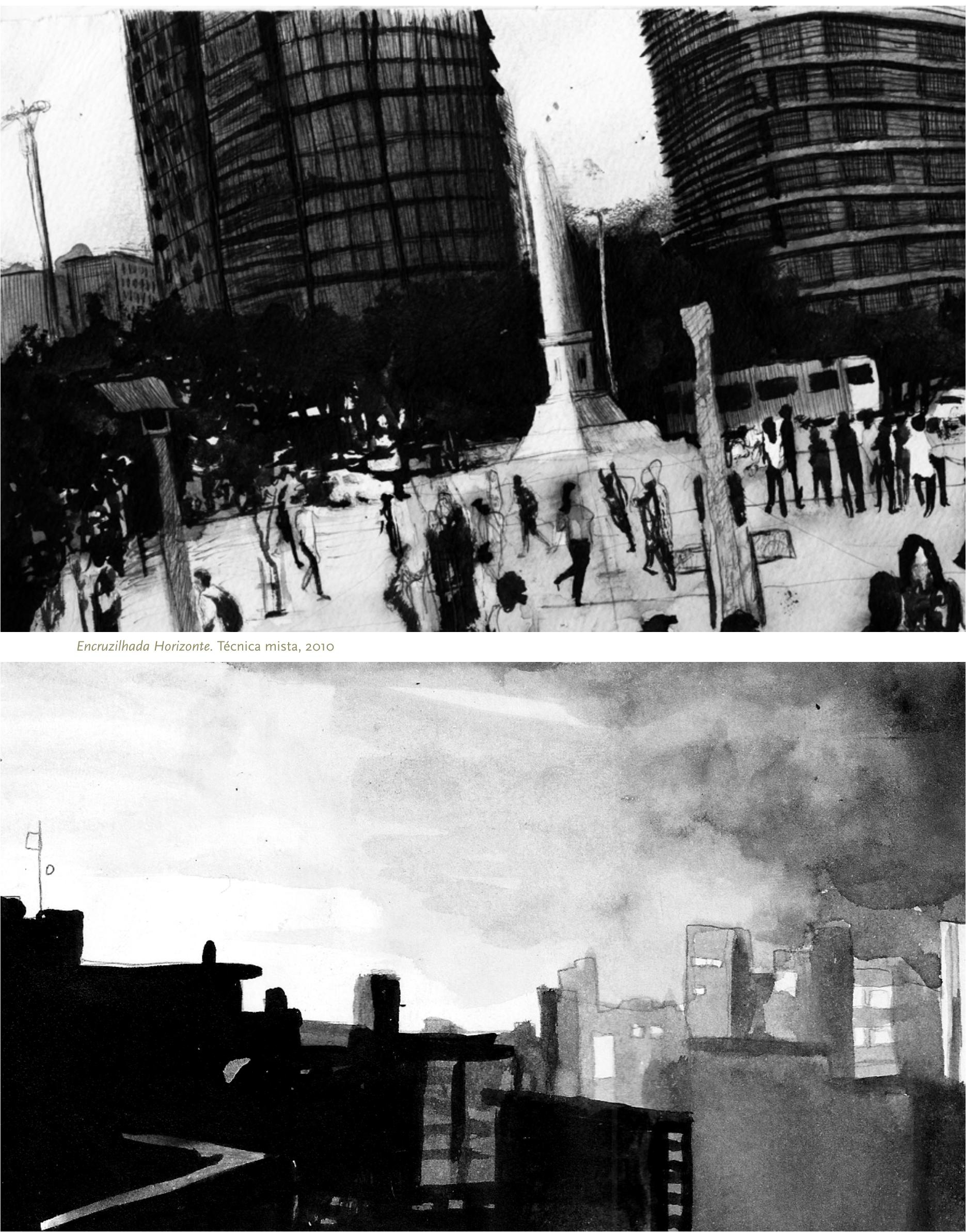


forma, as inovadoras coalizões trabalho-comunidade que vieram à tona podem ser consideradas como efeitos do transbordamento ou como Externalidades Jacobianas que surgiram desta imensa aglomeração dos trabalhadores imigrantes pobres.

Outra característica singular das novas coalizões trabalho-comunidade era sua alta conscientização das políticas de espaço e a potencial importância estratégica de buscar justiça espacial e o direito à cidade. Como discuto em Seeking Spatial Justice, a conscientização espacial relativamente maior dos movimentos locais e a emergência de estratégias especificamente espaciais do ativismo político derivam, em grande parte, das relações bem fundamentadas e contínuos vínculos entre os grupos ativistas e os estudantes universitários e faculdades envolvidas em planejamento urbano e, em menor grau, em geografia. À guisa de ilustração, pelo menos quarenta alunos do Departamento de Planejamento Urbano foram empregados nos últimos dez anos, aproximadamente, por LAANE na condição de estagiários, pesquisadores e organizadores. Também de importância no estabelecimento de um canal singularmente significativo entre a universidade e as maiores comunidades ativistas tem sido o Programa de Estudiosos da Comunidade (Community Scholars Program), por meio do qual ativistas experientes em assuntos trabalhistas e comunitários se conectaram ao departamento ao longo de um ano, participando de cursos, engajando-se em projetos com alunos de planejamento urbano e ainda intensificando o fluxo de mão dupla de ideias e incentivos.

Finalmente, e chegando a uma conclusão apropriada para um ensaio neste periódico que tece reflexões sobre o aniversário de dez anos da publicação de Postmetropolis, nenhuma outra cidade dos EUA testemunhou tamanho fluxo de novas ideias a respeito da teoria espacial, economia regional e geografia urbana entre o mundo universitário e o acadêmico e a comunidade geral da região urbana. Los Angeles, tanto quanto ou mais do que qualquer outro lugar, tem sido um foco ativo para a tradução da teoria espacial para a prática espacial. 


\section{Referências de "Para além de Postmetropolis" "23}

23. Algumas poucas referências incluídas aqui não foram citadas no texto, mas são relativas, de uma maneira ou de outra, ao meu pensamento e escritos após Postmetropolis.

SOJA, E. W. Regional Urbanization and the End of the Metropolis Era. In: BRIDGE, G.;

WATSON, S. (Ed.). Companion to the City. New York; London: Routledge, 2oria.

SOJA, E. W. From Metropolitan to Regional Urbanization. Chapter 42. In: LOUKAITOU-

SIDERIS, A.; BANERJEE, T. (Ed.). Companion to Urban Design. New York; London: Routledge, $20 I I b$.

SOJA, E. W. Regional Urbanization and the Future of Megacities. In: BUIJS, S.; TAN, W.;

TUNAS, D. (Ed.). Megacities: Exploring a Sustainable Future. Rotterdam: Oio Publishers, 2 oıоa.

p. $57-76$.

SOJA, E. W. Seeing Nature Spatially. In: ALBERTSON, D.; KING, C. (Ed.). Without Nature: A New Condition for Theology. New York: Fordham University Press, 20Iob. p. I8I-202.

SOJA, E. W. From Metropolitan to Regional Urbanization. In: De toekomst van de metropool. Pamphlet. Erneus Heerma Lecture-de Alliantie, 2009a. p. 3-I5.

SOJA, E. W. Cities and States in Geohistory. Theory and Society, 39, p. 36I-376, 2009 b.

SOJA, E. W. Resistance After the Spatial Turn. In: PUGH, J. (Ed.). What is Radical Politics

Today?. Basingstoke: Palgrave Macmillan, 2009c. p. 69-74.

SOJA, E. W. Regional Planning and Development Theories. In: KITCHIN, R.; THRIFT, N. (Ed.). International Encyclopedia of Human Geography. New York: Elsevier, 20ogd. p. 259-270.

SOJA, E. W. Taking Space Personally. In: WARF, B.; ARIAS, S. (Ed.). The Spatial Turn:

Interdisciplinary Perspectives. New York; London: Routledge, 2008a. p. II-35.

SOJA, E. W.; KANAI, M. The Urbanization of the World. In: BURDETT, R.; SUDJIC, D. The Endless City. New York; London: Phaidon, 2008b. p. 54-69.

SOJA, E. W. Postmetropolitan Psychasthenia: A Spatioanalysis. In: BAVO (Ed.). Urban Politics Now: Re-Imagining Democracy in the Neoliberal City. Rotterdam: NAi Publishers, 2007a. p. 78-93.

SOJA, E. W. Designing the Postmetropolis. Harvard Design Magazine, 25, p. 43-49, Fall 2006/

Winter 2007.

SOJA, E. W. Writing Geography Differently. Response to critical commentaries by Elspeth Graham and Barney Warf on Postmodern Geographies. Classics in Human Geography Revisited. Progress in Human Geography, 306, p. 812-820, $2006 \mathrm{a}$.

SOJA, E. W. Reflections on the Concept of Global City Regions. Spanish translation in Ekonomiaz (Basque Journal of Economics); edited English version in "Glocalogue", on-line magazine Artefact: Strategies of Resistance. Belgrade, 2006b. Disponível em: <http://artefact. miz.hr/_/_ao4/lang_en/theory_soja_en.htm>. 
SOJA, E. W. Borders Unbound: Globalization, Regionalism, and the Postmetropolitan Transition. In: KRAMSCH, O.; VAN HOUTUM, H.; ZIERHOFER, W. (Ed.). Bordering Space. Aldershot: Ashgate, 2005. p. 33-46.

SOJA, E. W. Writing the City Spatially. City, v. 7, n. 3, p. 269-280, nov. 2003 a.

SOJA, E. W. Tales of a Geographer-Planner. In: ECKSTEIN, B.; THROGMORTON, J. A. (Ed.). Story and Sustainability: Planning, Practice, and Possibilitiy in American Cities. Cambridge, Mass.: The MIT Press, 2003b. p. 207-224.

SOJA, E. W. Urban Tensions: Globalization, Economic Restructuring, and the Postmetropolitan Transition. In: BENERIA, L.; BISNATH, S. (Ed.). Global Tensions: Challenges and Opportunities in the World Economy. New York; London: Routledge, 2003c. p. 275-290.

SOJA, E. W.; EHRENFURT, R. The New Regionalism: A Conversation with Edward Soja. Critical Planning, v. 9, p. 5-12, Summer 2002a.

SOJA, E. W.; BORCH, C. Interview with Edward W. Soja: Thirdspace, Postmetropolis, and Social Theory. Distinktion, v. 4, p. II3-I2O, 2002b. (Danish journal of critical social theory).

SOJA, E. W.; MULDER, A. Restructuring the Industrial Capitalist City: Interview with Edward Soja. In: BROUWER, J.; MULDER, A.; MARTZ, L. (Ed.). Transurbanism. Rotterdam: V2_ Publishing/NAi Publishers, 2002c. p. 88-IOI.

SOJA, E. W.; BLAKE, E. Spatiality past and present: An interview with Edward Soja. Journal of Social Archeology, v. 22, p. 139-158, jun. 2002d.

SOJA, E. W. "Exploring the Postmetropolis" and "Afterword". In: MINCA, C. (Ed.). Postmodern Geography: Theory and Praxis. Oxford, UK; Malden, MA: Blackwell Publishers, 20ol. p. 37-56, 282-294.

SOJA, E. W. Fractal Los Angeles: The Restructured Geographies of the Postmetropolis. In: MAYR, A.; Meurer, M.; VOGT, J. (Ed.). Stadt und Region: Dynamik von Lebenwelten. Leipzig, 200Ia. p. 255-260.

SOJA, E. W. Postmetropolis: Critical Studies of Cities and Regions. Malden (Massachussets): Blackwell Publishers, 2000.

SOJA, E. W.; SCOTT, A. J.; AGNEW, J.; STORPER, M. Global City-Regions. In: SCOTT, A. J. (Ed.). Global City-Regions: Trends, Theory, Policy. Oxford; New York: Oxford University Press, 200Ib. p. II-3O.

SOJA, E. W. Putting Cities First: Remapping the Origins of Urbanism. In: BRIDGE, G.; WATSON, S. (Ed.). A Companion to the City. Oxford, UK; Malden, MA: Blackwell, 200oa. p. 26-34.

\section{Outras referências}

ASHEIM, B.; COOKE, P.; MARTIN, R. (Ed.). Clusters and Regional Development: Critical Reflections and Explorations. Abingdon, UK; New York: Routledge, 2006.

BRAKMAN, S.; GARRETSEN, H.; VAN MARREWIJK, C. The New Introduction to Geographical Economics. Cambridge: Cambridge University Press, 2009. 
BRENNER, N. New State Spaces: Urban Government and the Rescaling of Statehood. New York: Oxford University Press, 2005.

CURRY, A. Göbekli Tepe: The World's First Temple. Smithsonian Magazine, 2008. Disponível em: <http://www.smithsonianmag.com/history-archeology/gobekli-tepe>.

DAVIS, M. City of Quartz: Excavating the Future in Los Angeles. London: Verso, I990.

DAVIS, M. Planet of Slums. London: Verso, 2007.

DEAR, M. Urban Politics and the Los Angeles School of Urbanism. Urban Affairs, v. 22, p. 266-279, 2008.

DEAR, M.; DISHMAN, J. D. (Ed.). From Chicago to L.A.: Making Sense of Urban Theory. Thousand Oaks CA: Sage Publications, 200I.

FALUDI, A. The Megalopolis, the Blue Banana, and Global Economic Integration Zones in European Planning Thought. In: ROSS, C. L. (Ed.). Megaregions: Planning for Global Competitiveness. Washington, DC: Island Press, 2009. p. I8-34.

FALUDI, A.; WATERHOUT, B. The Making of the European Spatial Development Perspective: No Masterplan. London: Routledge, 2002.

FLORIDA, R. The Rise of Criative Class: How It's Transforming Work, Leisure, Community and Every Day Life. New York: Perseus Group Books, 2002.

GLAESER, E. L. et al. Growth in Cities. The Journal of Political Economy, v. Ioo, n. 6, p. II26II52, I992.

JACOBS, J. The Economy of Cities. New York: Random House, I969.

KRUGMAN, P. The New Economic Geography, Now Middle-aged. Paper prepared for presentation to the Association of American Geographers, Apr. I6, 2010. (Online).

MÄKI, U.; MARCHIONNI, C. Is geographical economics imperializing economic geography?. Journal of Economic Geography, Oxford University Press, 2010. (Online).

MARTIN, R. The new 'geographical turn' in economics: some critical reflections. Cambridge Journal of Economics, v. 23, p. 65-91, I999.

OHMAE, K. The Rise of the Region-State. Foreign Affairs, v. 71, p. 78-87, I993.

ROBERT JR., L. On the Mechanics of Economic Development. Journal of Monetary Economics, v. 22,1988, p. 3-42.

ROSS, C. (Ed.). Megaregions: Planning for Global Competitiveness. Washington, DC: Island Press, 2009. (Foreword by Richard Florida).

SCOTT, A. Creative Cities: Conceptual Issues and Policy Questions. Journal of Urban Affairs, v. 28, p. I-I7, 2006.

STORPER, M. The Regional World: Territorial Development in a Global Economy. New York: The Guilford Press, I997.

STORPER, M.; VENABLES, A. J. Buzz: Face-to-Face Contact and the Urban Economy. Journal of Economic Geography, v. 4, p. 35I-370, 2004. 